\title{
Long-term ecological research in the forests of the United States: Key lessons for its application in Chile and around the world
}

\author{
Estudios ecológicos de largo plazo en bosques de Estados Unidos: Lecciones claves para \\ su aplicación en Chile y otras regiones
}

\author{
JERRY F. FRANKLIN ${ }^{1} \&$ MARK E. SWANSON 2, * \\ ${ }^{1}$ Box 352100, College of Forest Resources, University of Washington, Seattle, WA, 98195-2100 \\ ${ }^{2}$ Box 646410, Department of Natural Resource Sciences, Washington State University, Pullman, WA 99164-6410 \\ *Corresponding author: markswanson@wsu.edu
}

\begin{abstract}
Long-term ecological research addresses questions to which short-term research projects cannot effectively respond because of the temporal scales over which many ecosystem processes operate. In North America, this type of research has yielded important information on key processes and organisms in many forest types, from eastern broadleaf forests to the coniferous forests of the west, and from tropical to boreal latitudes. Long-term ecological research (that conducted at the decade scale or longer) in the forests of North America has included watershed studies, silvicultural trials, establishment of permanent plots to assess forest demographics, and the study of disturbance regimes and predator-prey systems. Instituting such research in forest ecosystems of other regions of the world, especially at corresponding latitudes on either side of the equator, will help scientists understand patterns of natural disturbance and succession, the effects of alternative management strategies, and the impacts of climate change. Key recommendations based on North American long-term ecological research include: 1) the importance of multidisciplinary research, 2) the need to invest in data storage and management, 3) the deployment of both basic and advanced technology (e.g., eddy covariance systems), and 4) development of collaboration networks among regions, institutions, and individual researchers.
\end{abstract}

Key words: demographics, long-term ecological research, multidisciplinary, watersheds, wildlife.

\section{RESUMEN}

La investigación ecológica de largo plazo es capaz de abordar ciertas preguntas de una manera mejor que los proyectos de corto plazo, debido a las escalas temporales en que funcionan muchos procesos ecológicos. En Norteamérica, este tipo de investigación ha brindado conocimiento sobre importantes procesos y organismos claves en muchos tipos forestales, extendiéndose desde los bosques caducifolios de la costa este a los bosques de coniferas en la costa oeste, y en latitudes tropicales hasta boreales. La investigación ecológica de largo plazo en los bosques de Norteamérica ha incluido estudios de cuencas, ensayos silviculturales, establecimiento de parcelas permanentes para investigar demografía forestal, y el estudio de regímenes de perturbación y sistemas predadores/presa. El inicio de investigación de largo plazo en ecosistemas forestales de otras regiones del mundo, especialmente en latitudes correspondientes a ambos lados del ecuador, ayudará a los científicos a comprender los regímenes de perturbaciones naturales y sucesión, así como los efectos de varias estrategias del manejo forestal, y los impactos de cambio climático. Recomendaciones claves basadas en la experiencia de Norteamérica incluyen: 1) la importancia de la investigación multidisciplinaria, 2) la necesidad de invertir recursos en el manejo de bases de datos, 3) la aplicación tanto de tecnología básica como avanzada (por ejemplo, sistemas de detección de 'eddy covariance' para cuantificar el intercambio de carbono entre los bosques y la atmósfera), y 4) colaboración entre regiones, instituciones, y científicos individuales.

Palabras clave: cuencas hidrológicas, demografía, investigación ecológica del largo plazo, multidisciplinario, vida silvestre. 


\section{INTRODUCTION}

The science of ecology made great advances in the last half of the twentieth century. Old ecological paradigms were modified or discarded and new ones created with the goal of making them more applicable to the daunting task of conserving and managing ecosystems for multiple values.

A key development in ecological understanding and research was the realization that no ecological phenomenon could be fully understood by addressing a single spatial or temporal scale (Levin 1992). Technologies such as remote sensing have aided in solving problems associated with ecological research at larger spatial scales, but addressing long temporal scales remains a challenge. Some processes, especially in longlived forest ecosystems, can only be definitively understood based on research conducted over much longer periods of time than is typical of most research projects. Longterm ecological research came to occupy an important niche in North American forest ecology, answering many questions and inspiring new avenues of research (Franklin 1989, 2005). Focal examples of long-term ecological research in North American forest ecosystems are provided in this paper (Table 1) along with some discussion about the importance of this research in influencing scientific understanding and policy formation. We conclude the paper with some recommendations for the conduct and application of this type of work in other areas of the world.

\section{SPECIFIC EXAMPLES OF LONG-TERM ECOLOGICAL RESEARCH IN FORESTS OF THE UNITED STATES}

\section{Permanent sample plots}

Permanent plots yield critical insights into the demographic processes of plant communities, especially those dominated by long-lived trees. Much insight has been yielded by 'trading space for time' in the application of chronosequence methods to forest ecosystems, but there are drawbacks to this method (Pickett 1989, Bakker et al. 1996).
Scientists in the early United States Forest Service recognized the value of establishing permanent sample plots to observe natural and managed stand development (Franklin et al. 1972). For example, as early as 1910, Forest Service scientists such as Leo A. Isaac and Thornton T. Munger were establishing permanent sample plots in naturallyregenerated Douglas-fir (Pseudotsuga menziesii (Mirb.) Franco) stands in the Wind River Valley in Washington state (Curtis et al. 2007). Many of these plots are still in existence, yielding valuable data on the development of mature stands. For example, Franklin and DeBell (1988) used data from thirty-six years of observation of plots in the Wind River Experimental Forest to estimate mortality rates and describe successional dynamics in old-growth Douglas-fir/western hemlock (Tsuga heterophylla (Raf.) Sarg.) forests.

The potential for significant changes in forest demographics, structure, and composition due to climate change or the introduction of exotic diseases presents another compelling application of data from permanent sample plots. Longitudinal assessment of permanent plots from across the western United States demonstrates that mortality rates have increased in the latter half of the $20^{\text {th }}$ century (van Mantgem et al. 2009). Long-term data (1934-present) from permanent plots at the Coweeta Hydrologic Laboratory in North Carolina enabled researchers to assess the impacts of logging and the loss of the American chestnut (Castanea dentata (Marsh.) Borkh.) to an introduced fungus on tree diversity and distribution at watershed scales (Elliott \& Swank 2008). At the Bonanza Creek Long Term Ecological Research Site in Alaska, long-term studies are documenting how climate change might influence ecosystem development, carbon storage, and various boreal and arctic habitat types (Turner et al. 2003, Chapin et al. 2006). Insights such as these are difficult or impossible to obtain without investments in long-term maintenance of permanent plots.

\section{Silvicultural trials}

The effects of silvicultural interventions on forest stand composition, structure, and function include both short-term and long-term 
impacts, with most responses becoming measurable over long periods. Long-term forest measurements are not novel to European forestry practitioners (Puettmann et al. 2009), and have played a key role in the development of silvicultural practice there. With the advent of forestry as a profession and an acceptable form of land management in North America, long-term observations of silvicultural experiments have provided tremendous insight into the response of forest ecosystems to different practices. In the early part of the $20^{\text {th }}$ century, various types of selective cutting were studied in many locales as alternatives to clearcutting or high-grading practices associated with unregulated timber harvest (Seymour et al. 2006). An excellent example is the establishment of silvicultural trials of a number of methods (including untreated controls) in northern hardwood forests of the Upper Peninsula of Michigan, in the north-central United States (Eyre \& Zillgitt 1953). These trials provided some of the earliest data to support the development of uneven-aged silvicultural systems in North America.

Even responses involving the understory require years of monitoring for full understanding, such as the recovery of shrub communities following thinning treatments (Chan et al. 2006). Busse et al. (1996), using data from a long-term experiment in spacing and understory removal in ponderosa pine, found that stand responses to presence of an understory changed over time. This demonstrates the importance of long-term observation in determining the changing role of functional components of a forest throughout succession.

The latter part of the $20^{\text {th }}$ century, characterized by mounting concerns around ecosystem health and conservation of endangered species, brought a focus on natural ecosystem function and its biodiversity to silvicultural trials. These trials differed from previous efforts in that they measured new sets of ecological response variables (such as response of bryophytes or mycorrhizal fungi), tested novel silvicultural methods developed in response to specific ecological requirements, or both (see Peterson \& Maguire 2005). For example, the Demonstration of Ecosystem Management Options (DEMO) study, a long- term, rigorously designed trial, was instituted in the early 1990's to test the effects of different levels and patterns of variable retention on biodiversity and ecosystem function (Aubry et al. 2004).

\section{Prescribed fire and restoring disturbance regimes}

The recognition that humans have disrupted disturbance regimes in many forest ecosystems has led to long-term research on the effects of restoring natural disturbance regimes in many parts of North America. For example, research personnel in Sequoia-Kings Canyon and Yosemite National Parks have monitored the effects of prescribed burning for almost forty years (Arno \& Fiedler 2005; Parsons \& van Wagtendonk 1996). This program, begun in response to a special report to the Secretary of the Interior on the management of western National Parks (Leopold et al. 1963, as cited in Arno \& Fiedler 2005), has been successful in reducing ladder fuels, restoring herb/shrub understory plant communities, and encouraging regeneration of giant sequoia (Sequoiadendron giganteum (Lindl.) Buchholz). Monitoring procedures after individual fire events trace recovery of plant communities and quantify changes in fuelbed characteristics.

The Lubrecht Experimental Forest in western Montana provides another case study of restoring functionality to a system where disturbance regimes have been disrupted by human activity. Forest stands originally dominated by widely-spaced ponderosa pines (Pinus ponderosa Douglas ex Lawson et C. Lawson) have become dense with relatively shade-tolerant Douglas-fir following the longterm exclusion of low-severity fire. Various silvicultural treatments were implemented to reduce the density of Douglas-fir, followed by the reintroduction of prescribed fire to a subset of the treatment plots. Twenty years of monitoring by Stephen F. Arno and colleagues have shown that the combination of initial mechanical treatment followed by the resumption of frequent fire is effective to enhance vigor in all age classes of ponderosa pine, dramatically reduce the density of Douglas-fir, and decrease mortality rates of pine to drought, high-severity fire, and insect attack (Arno \& Fiedler 2005). 


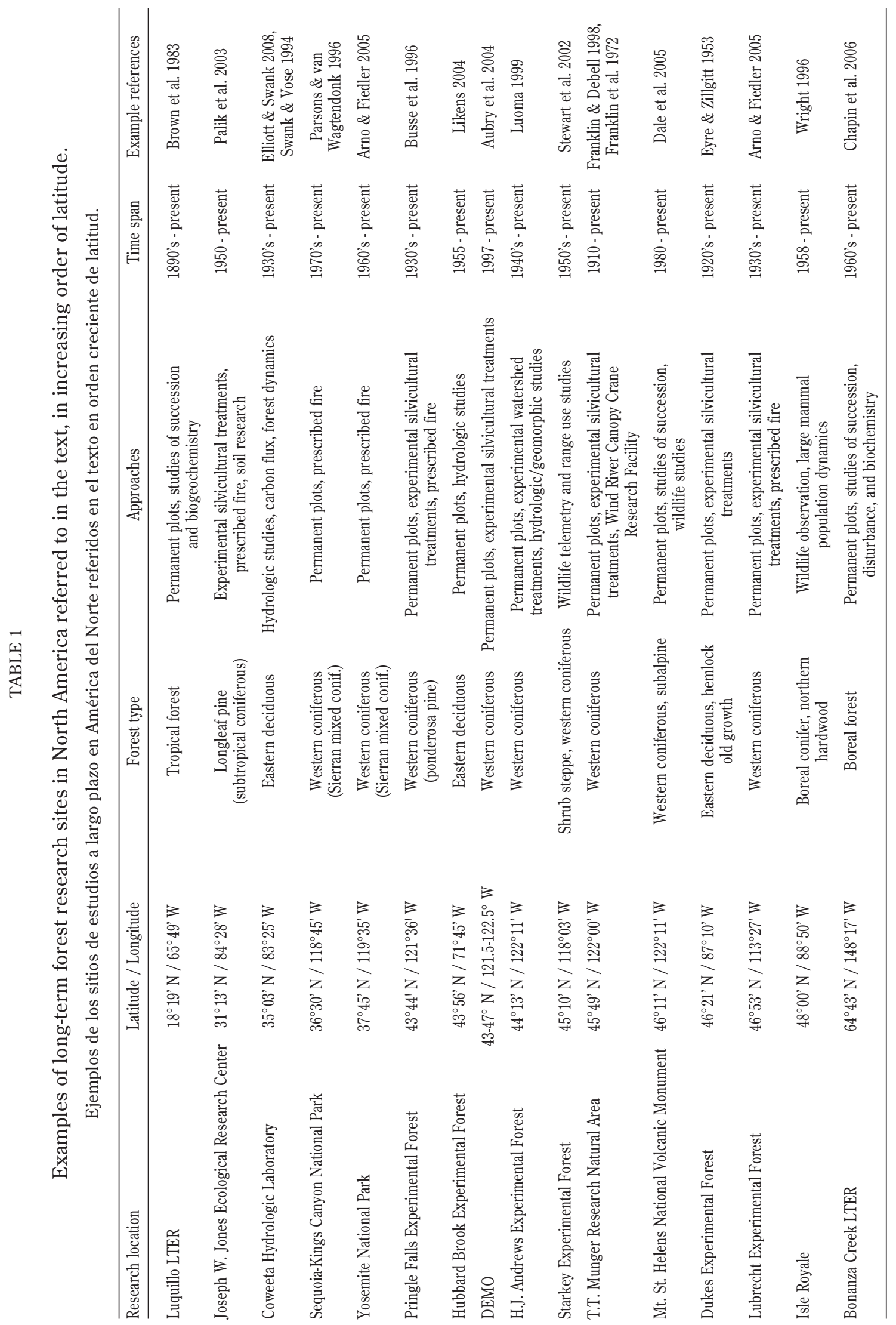


There are numerous other forested regions of the United States where long-term studies of fire regime restoration have been conducted, including the longleaf pine (Pinus palustris $\mathrm{F}$. Michaux [Kral 1993]) savannas of the southeastern United States (e.g., the Jones Ecological Research Center, Georgia, located on the Ichauway Plantation) and the shortleaf pine (Pinus echinata Miller 1768) forests of Missouri's Ozark Mountains (Guldin 2004). In most (if not all locations), evidence from longterm research suggests that prescribed or unsuppressed lightning fire, often in combination with mechanical treatment, can restore forest structures and compositions that occurred prior to the advent of fire suppression.

\section{Watershed studies}

Some of the earliest long-term research efforts in the United States were conducted to gain understanding into watershed processes, especially the influence of timber harvest and other land management practices on water yield and quality. The Hubbard Brook LTER site in New Hampshire is one of the bestknown examples of watershed studies of this type. Hubbard Brook has yielded numerous insights into the impact of forest management activities on ecosystem function including the important role of surviving vegetation in preventing significant losses of nutrients following timber harvest (Likens 2004). In addition, this research demonstrated that the rate at which nutrient losses returned to preharvest levels varied with each particular nutrient. The Coweeta Hydrological Laboratory in North Carolina has an even longer history of watershed research with many seminal findings. One of these involved the conversion of watershed covered with mixed-hardwood forest to a conifer plantation; significantly reduced streamflows was a consequence of this conversion (Swank \& Vose 1994).

Watersheds are integrators of effects originating far beyond the watershed boundaries, and long periods of record may be required to understand emergent behaviors. The net export of base cations from a watershed as an impact of acid precipitation, and subsequent recovery following reductions in the acidity of precipitation, was documented by Likens et al. (1996) using long-term hydrological data sets from Hubbard Brook.

At the H.J. Andrews Experimental Forest in central Oregon watershed-level impacts of forest management practices have been demonstrated using several sets of paired watersheds. Results of these studies include the discovery of the disproportionate impacts that forest roads have on hydrology and slope stability. Research continues today at the Andrews Experimental Forest on hydrology, geomorphology, and soils in forested watersheds (Luoma 1999). The long period of record at this site has included major flood events, emphasizing the importance of long term research to 'capture' infrequent events that are a critically important part of the natural range of variability.

\section{Wildlife management}

Long-term research is less common in the field of wildlife biology than in forest management, but three important examples merit mention due to their importance for long-term forest structure and spatial pattern. Wolves (Canis lupus L.) and moose (Alces alces L.) have coexisted on Michigan's Isle Royale since the winter of 1948-1949, and their interactions and biology there have been studied continuously since 1958 (Wright 1996). The long-term datasets generated by these studies have allowed researchers to address questions about the stability of predator-prey systems, the relative importance of top-down and bottom-up influences on herbivore populations, and many other ecological phenomena. This research program has also attracted other researchers to Isle Royale, another example of a long-term ecological research program facilitating additional efforts. Reintroduction of wolves to Yellowstone National Park in the states of Wyoming and Montana provides a second example; this research allowed researchers to document the cascading impacts of the restoration of a keystone predator to an otherwise intact ecosystem (e.g., Ripple \& Beschta 2003). Finally, the Starkey Experimental Forest in Oregon, 
established in the 1950's, has provided invaluable data on the effects of elk and cattle grazing, hunting, and land management practices on forest and range resources (Lugo et al. 2006). A notable contribution of the Starkey Experimental Forest is the inclusion of many studies on human needs and impacts in relation to the ecosystem; direct studies of social impacts have not been characteristic of many long-term research projects, although they are increasingly a component of the National Science Foundation-sponsored LongTerm Ecological Research projects and are explicit components of the National Ecological Observatory Network (NEON) program.

\section{Studies of natural disturbances}

Intense large natural disturbances are important ecological phenomena which make the patterns and rates of ecological recovery a topic of great interest. The eruptive cycle at Mount St. Helens in the state of Washington that began in May of 1980 created a large area $\left(>500 \mathrm{~km}^{2}\right.$ ) affected by a complex of disturbances. Initially scientists hypothesized that the eruption was going to provide an opportunity to study primary succession; in fact, an immense variety of organisms survived the eruption and contributed to a wide variety of recovery pathways. The concept of "biological legacies" emerged from the early studies of ecological recovery at Mount St. Helens; biological legacies are the living organisms and propagules, dead organic matter (including such large organic structures as dead trees and down $\log$ s), and organically-derived patterns (such as in soil properties) that survive from a pre-disturbance ecosystem to participate in the development of a post-disturbance ecosystem (Franklin et al. 2000). Permanent research plots in the blast zone created by the volcano have yielded insights into spatio-temporal patterns of plant colonization (del Moral \& Eckert 2005), the importance of pioneering plant taxa in ecosystem recovery (del Moral \& Rozzell 2005), small mammal dynamics in earlysuccessional environments (Crisafulli et al. 2005), and many other phenomena related to ecosystem resilience (Dale et al. 2005). This research has also led to an increased appreciation of the importance of the pre-forest stage of succession that occurs in the period between the disturbance and re-establishment of tree canopy closure (i.e., occupancy of the site by a new forest). The vascular plant flora and communities in areas of the blast zone that were left to recover via natural processes have become sharply distinct from areas that were salvage-logged and regenerated with conifer plantations, as is typically done in the region (Titus \& Householder 2007); long term research in this field will have profound implications for post-disturbance management policy, applicable to both natural and anthropogenic disturbances. For example, the concept of biological legacies has led to the development of variable-retention regeneration harvest systems that lifeboat many elements of biological diversity during timber harvests. Like many long-term research programs, the work at Mt. St. Helens was well-funded initially (largely due to the publicity surrounding the eruption), but suffered attrition of resources in the decades following the event.

Long-term research comparable to that conducted at Mount St. Helens has been carried out following many other large disturbances including the Yellowstone Fires of 1988, several Caribbean hurricanes, and major wind storm events. Responses consistently show that ecosystems quickly regain functional capabilities following such events -largely as a result of biological legacies- and that human activities, such as salvage logging, often interfere with natural recovery processes.

\section{Research natural areas}

Especially in the Pacific Northwest, special ecosystems or examples of specific successional conditions have merited designation as "research natural areas" where other land uses, especially extractive activities, are excluded (Franklin et al. 1972). Long-term research plots in such locations have yielded valuable data on forest types such as exceptionally old forest (e.g., Cedar Flats Research Natural Area in Washington State), high-biomass sites (e.g., the noble fir stands at Goat Marsh Research Natural Area) and edaphic climax (e.g., serpentine or wetland) forests. 


\section{IMPACTS ON POLICY}

Long-term ecological research efforts have played a critical role in determining or confirming environmental policy. Research at Hubbard Brook Experimental Forest has had many important influences on policy, including policies related to acid precipitation and clearcutting; another example is the research on lead inputs through precipitation at Hubbard Brook, which demonstrated the effectiveness of regulating lead content in gasoline (Likens 2004). The multitude of longterm studies conducted at the H.J. Andrews Experimental Forest, as well as studies that were inspired by long-term investments in research at that location, played a central role in changes in federal forest policy in the Pacific Northwest (Lugo et al. 2006). The major shift in goals for management of the national forests -from timber production to biological diversity and ecosystem processeswas driven by the long-term research on forest ecosystems, including forest-stream interactions; the Northwest Forest Plan for federal forest land within the range of the northern spotted owl (Strix occidentalis caurina Merriam) exemplifies the change and the role of ecosystem science in resolving this paradigm shift. Efforts focused on recovery and restoration of large carnivores, such as wolves and grizzly bears (Ursus arctos L.), represents another key change in wildlife policy that arose partly from long-term research on the ecological roles of these organisms. Long-term observation and research on forests in the interior west of North America have profoundly changed land managers' attitudes towards fire as an ecological process, leading to greater acceptance of natural and prescribed fires in forest management regimes (Arno \& Fiedler 2005, Cissel et al. 1999).

\section{RECOMMENDATIONS AND GENERAL COMMENTS}

The North American experience in long-term ecological research suggests that such efforts are instrumental in definitively addressing many of the working hypotheses that form the basis for forest management and ecology of natural disturbance. The following are some suggestions for new ventures into long-term ecological research.

\section{Be interdisciplinary}

Long-term ecological research installations often serve as 'gathering points' for experts representing multiple disciplines. An excellent example is from the H.J. Andrews Experimental Forest, where foresters, hydrologists, geomorphologists, and other specialists were brought together under the auspices of the International Biological Programme (Luoma 1999). The inclusion of specialists from diverse backgrounds goes a long way towards ensuring that important variables are not ignored, that experimental designs will have a measurable impact, and that a holistic perspective on ecosystem function is gained as a result of research.

\section{Have a set of central questions or focal areas of research}

As research on old-growth forests became a rallying point for researchers at the H.J. Andrews, or as watershed function was a focal theme for researchers at Hubbard Brook, so should new endeavors have a central theme or themes to organize and motivate a diverse set of collaborators. Climate change, loss of native biodiversity, carbon cycling, conservation of watershed productivity, and similar topics are overarching themes that can establish relevance between disparate areas of research and provide common ground for long term research efforts.

\section{Include statisticians from the beginning}

Long-term research designs must be statistically robust. Principles of modern experimental design, including the use of controls and replication, plots of sufficient size for multiple types of research, random assignment of treatments, and pre-treatment or baseline measurements in all replicates, greatly increases the potential for long-term research to yield robust results (Powers \& van Cleve 1991, Ford 2005). Application of the "kiss" principle ("Keep it simple, Stupid") is also highly recommended to avoid swamping experiments (and losing potential for 
significant inferences) by trying to include excessive numbers of treatment variables (Franklin 2005). Both observational and experimental approaches will be necessary to answer many scientific questions related to socio-ecological challenges. Experience from the U.S. Long-Term Ecological Research (LTER) program suggests that data management will occupy at least $25 \%$ of the operational budget (Franklin 2005). The inclusion of sufficient expertise in database creation and maintenance in any long-term ecological research effort cannot be overstated.

\section{Welcome both old and new approaches}

Instrument arrays will become increasingly important, but traditional plot methods should not be discarded. A number of sensor types have been developed to measure important ecosystem functions such as carbon flux and transpiration, and these are being deployed in long-term research facilities around the world. For example, eddy-covariance carbon flux measurements at the Wind River Canopy Crane Research Facility in Washington State have demonstrated the link between interannual climatic variation and net carbon flux from old-growth forests, as well as countering the idea that old-growth forests are insignificant carbon sinks (Paw U et al. 2004). However, traditional approaches to investigating forest ecosystems, such as fixeddimension permanent sample plots should be retained to provide baseline data and context for technologically sophisticated approaches; it is imperative that, ultimately, empirical data are required for definitive testing of hypotheses and models.

\section{Collaborate}

Collaboration with other researchers at national and global scales is necessary to generate globally-relevant synthesis and context for local findings. An excellent example of this is the U.S. Long-Term Ecological Research (LTER) program, a funded program of the National Science Foundation (NSF). This program has given rise to several efforts to compare and synthesize findings from across sites (Franklin et al. 1990). This serves to advance ecological theory, in addition to deepening understanding of individual ecosystems. National- and globalscale collaboration is especially important for long-term assessment of ecosystem responses to global climate change, which operates at multiple spatial and temporal scales. Results from one site may be misleading if not interpreted in the context of results from multiple sites across environmental gradients at regional and continental scales (Levin 1992) and in both hemispheres.

\section{Be flexible}

Long-term research can generate answers to pre-defined questions, but it also can be a powerful catalyst for opportunistically investigating phenomena that come to attention during the course of research. Events such as infrequent or atypical disturbances, while a disruption to previous lines of research, may also be viewed as tremendous opportunities to gain new ecological insights.

\section{Be determined}

Research funding allocation is largely governed by short-term political interests (Franklin 1989, Wright 1996). Maintaining long-term research over the years and decades requires dedicated individuals who can be flexible in pursuing funding, aggressive in communicating research importance to policymakers, and diplomatic in accommodating the concerns of participating scientists and other professionals. Institutional commitment is a hallmark of successful long term ecological research programs (Powers \& van Cleve 1991).

Long-term ecological research has been conducted in North American forest ecosystems ranging from the tropics to the subarctic, from sea level to subalpine ecosystems, in humid and xeric forests, on low and high productivity sites, and in both urbanfringe and remote environments. These diverse efforts have influenced watershed management, habitat conservation, fire management and suppression, timber harvest practices, and a host of other crucially important human activities. This type of research has proved to be an important 
investment in forest ecosystems for ecological, economic, and social values. It is greatly encouraging that the scientific community and academic institutions in Chile are seriously engaged in the process of initiating long-term ecological research at a national scale (Anderson et al. 2008). The data generated by these efforts may be compared to areas of climate and latitude similar to those in Chile, such as the west coast of North America (Lawford et al. 1996) offering powerful insights into the response of biotic communities across the two hemispheres to climate change. This investment of time and resources may prove critically important in generating the type of ecological and socio-ecological knowledge necessary to achieve sustainability in a dynamic world.

\section{SUPPLEMENTARY MATERIAL}

The Spanish version of this article is available as online Supplementary Material at http:// rchn.biologiachile.cl/suppmat/2010/1/SM Franklin_\&_Swanson_2010.pdf

\section{LITERATURE CITED}

ANDERSON CB, R ROZZI, GE LIKENS, JR GUTIÉRREZ, A POOLE \& JJ ARMESTO (2008) Using long-term socio-ecological study sites to integrate research with society. Environmental Ethics 30: 295-312.

ARNO SF \& CE FIEDLER (2005) Mimicking Nature's fire: Restoring fire-prone forests in the West. Island Press, Washington, DC.

AUBRY KB, CB HALPERN \& DA MAGUIRE (2004) Ecological effects of variable-retention harvests in the northwestern United States: The DEMO study. Forest Snow and Landscape Research 78: 119-137.

BAKKER JP, H OLFF, JH WILLEMS \& M ZOBEL (1996) Why do we need permanent plots in the study of long-term vegetation dynamics? Journal of Vegetation Science 7: 147-155.

BROWN S, AE LUGO, S SILANDER \& L LIEGEL (1983) Research history and opportunities in the Luquillo Experimental Forest. Gen. Tech. Rep. SO-44. U.S. Department of Agriculture, Forest Service, Southern Forest Experiment Station, New Orleans, LA.

BUSSE MD, PH COCHRAN \& JW BARRETT (1996) Changes in ponderosa pine site productivity following removal of understory vegetation. Soil Science Society of America Journal 60: 16141621.

CHAN SS, DJ LARSON, KG MAAS-HEBNER, WH EMMINGHAM, SR JOHNSTON \& DA
MIKOWSKI (2006) Overstory and understory development in thinned and underplanted Oregon Coast Range Douglas-fir stands. Canadian Journal of Forest Research 36: 26962711.

CHAPIN F S, MW OSWOOD, K VAN CLEVE, LA VIERECK \& DL VERBYLA (eds) (2006) Alaska's changing boreal forest. Oxford University Press, New York.

CISSEL JH, FJ SWANSON \& PJ WEISBERG (1999) Landscape management using historical fire regimes: Blue River, Oregon. Ecological Applications 9: 1217-1231.

CRISAFULLI CM, JA MACMAHON \& RR PARMENTER (2005) Small-mammal survival and colonization on the Mount St. Helens volcano: 1980-2002. In: Dale VH, FJ Swanson \& CM Crisafulli (eds) Ecological responses to the 1980 eruption of Mount St. Helens: 199-218. Springer, New York.

CURTIS RO, DS DEBELL, RE MILLER, M NEWTON, JB ST CLAIR \& WI STEIN (2007) Silvicultural research and the evolution of forest practices in the Douglas-fir region. Gen. Tech. Rep. PNWGTR-696. U.S. Department of Agriculture, Forest Service, Pacific Northwest Research Station, Portland, Oregon.

DALE VH, FJ SWANSON, CM CRISAFULLI (eds) (2005) Ecological responses to the 1980 eruption of Mt. St. Helens. Springer Verlag, New York.

DEL MORAL R \& AJ ECKERT (2005) Colonization of volcanic deserts from productive patches. American Journal of Botany 92: 27-36.

DEL MORAL R \& LR ROZZELL (2005) Long-term effects of Lupinus lepidus on vegetation dynamics at Mount St. Helens. Plant Ecology 181: 203-215.

ELLIOTT KJ \& WT SWANK (2008) Long-term changes in forest composition and diversity following early logging (1919-1923) and the decline of American chestnut (Castanea dentata). Plant Ecology 197: 155-172.

EYRE FH \& WM ZILLGITT (1953) Partial cuttings in northern hardwoods of the Lake States: Twentyyear experimental results. Technical bulletin 1076. United States Department of Agriculture, Washington, DC

FORD ED (2005) Where can we go from here? In: Peterson CE \& DA Maguire (eds) Balancing ecosystem values: Innovative experiments for sustainable forestry: Proceedings of a conference: 327-329. Gen. Tech. Rep. PNW-GTR635. U.S. Department of Agriculture, Forest Service, Pacific Northwest Research Station, Portland, Oregon.

FRANKLIN JF (1989) Importance and justification of long-term studies in ecology. In: Likens GE (ed) Long-term studies in ecology: Approaches and alternatives: 3-19 Springer-Verlag, New York.

FRANKLIN JF (2005) Long-term studies: the basis for science based resource management. pp. 13-14. In: Peterson CE \& DA Maguire (eds), Balancing ecosystem values: Innovative experiments for sustainable forestry: Proceedings of a conference. Gen. Tech. Rep. PNW-GTR-635. U.S. Department of Agriculture, Forest Service, Pacific Northwest Research Station, Portland, Oregon.

FRANKLIN JF, FC HALL, CT DYRNESS \& C MASER (1972) Federal research natural areas in Oregon 
and Washington: A guidebook for scientists and educators. U.S. Department of Agriculture, Forest Service, Pacific Northwest Forest and Range Experiment Station, Portland, OR.

FRANKLIN JF \& DS DEBELL (1988) Thirty-six years of tree population change in an old-growth Pseudotsuga-Tsuga forest. Canadian Journal of Forest Research 18: 633-639.

FRANKLIN JF, CS BLEDSOE \& JT CALLAHAN (1990) Contributions of the Long-Term Ecological Research program. Bioscience 40: 509-523.

FRANKLIN JF, DB LINDENMAYER, JA MACMAHON, A MCKEE, J MAGNUSON, DA PERRY, R WAIDE \& D FOSTER (2000) Threads of continuity: Ecosystem disturbance, recovery, and the theory of biological legacies. Conservation Biology in Practice 1: 8-16.

GULDIN JM (2004) Overview of ecosystem management research in the Ouachita and Ozark Mountains: Phases I-III. In: Guldin JM (ed) Ouachita and Ozark Mountains symposium: Ecosystem management research. Gen. Tech. Rep. SRS-74. U.S. Department of Agriculture Forest Service, Southern Research Station, Asheville, NC.

LAWFORD RG, ALABACK P \& E FUENTES (eds) (1996) High latitude rain forests and associated ecosystems of the west coast of the americas: Climate, hydrology, ecology and conservation. Springer Verlag, New York.

LEOPOLD AS, SA MCCAIN, CM COTTAM, JM GABRIELSON \& TL KIMBALL (1963) Wildlife management in the national parks. Transactions of the North American Wildlife and Natural Resources Conference 28: 28-45.

LEVIN SA (1992) The problem of pattern and scale in ecology: The Robert H. MacArthur Award Lecture. Ecology 73: 1943-1967.

LIKENS GE (2004) Some perspectives on long-term biogeochemical research from the Hubbard Brook Ecosystem Study. Ecology 85: 2355-2362.

LIKENS GE, CT DRISCOLL \& DC BUSO (1996) Longterm effects of acid rain: Response and recovery of a forest ecosystem. Science 272: 244-246.

LUGO AE, FJ SWANSON, O RAMOS-GONZALEZ, MB ADAMS, B PALIK et al. (2006) Long-term research at the USDA Forest Service's Experimental Forests and Ranges. Bioscience 56, 39-48.

LUOMA JR (1999) The hidden forest: The biography of an ecosystem. Henry Holt and Company, New York.

PALIK B, RJ MITCHELL, S PECOT, MA BATTAGLIA \& M PU (2003) Spatial distribution of overstory retention influences resources and growth of longleaf pine seedlings. Ecological Applications 13: $674-686$.

PARSONS DJ \& JW VAN WAGTENDONK (1996) Fire research and management in the Sierra Nevada National Parks. In: Halvorson WL \& GE Davis (eds) Science and ecosystem management in the
National Parks: 25-48. The University of Arizona Press, Tucson, Arizona.

PAW U KT, M FALK, TH SUCHANEK, SL USTIN, J CHEN et al. (2004) Carbon dioxide exchange between an old-growth forest and the atmosphere. Ecosystems 7: 513-524.

PETERSON CE \& DA MAGUIRE (eds) (2005) Balancing ecosystem values: Innovative experiments for sustainable forestry: Proceedings of a conference. Gen. Tech. Rep. PNW-GTR-635. U.S. Department of Agriculture, Forest Service, Pacific Northwest Research Station, Portland, Oregon.

PICKETT STA (1989) Space-for-time substitution as an alternative to long-term studies. In: Likens GE (ed) Long-term studies in ecology. Approaches and alternatives: 110-135. Springer-Verlag, New York.

POWERS RF \& K VAN CLEVE (1991) Long-term ecological research in temperate and boreal forest ecosystems. Agronomy Journal 83: 11-24.

PUETTMANN KJ, KD COATES \& C MESSIER (2009) A critique of silviculture: Managing for complexity. Island Press, Washington, DC.

RIPPLE WJ \& RL BESCHTA (2003) Wolf reintroduction, predation risk, and cottonwood recovery in Yellowstone National Park. Forest Ecology and Management 184: 299-313.

SEYMOUR RS, J GULDIN, D MARSHALL \& B PALIK (2006) Large-scale, long-term silvicultural experiments in the United States: Historical overview and contemporary examples. Allgemeine Forst und Jagd-Zeitung 177: 104-112.

SWANK WT \& JM VOSE (1994) Long-term hydrologic and stream chemistry responses of southern Appalachian catchments following conversion from mixed hardwoods to white pine. In: Landolt $\mathrm{R}$ (ed) Hydrologie kleiner Einzugsgebiete: Gedenkschrift Hans M Keller. Beitrage Zur Hydrologie der Schweiz 35. Bern, Schweizerische: Schweizerische Gesellschaft fur Hydrologie und Limnologie: 164-172.

TITUS JH \& E HOUSEHOLDER (2007) Salvage logging and replanting reduce understory cover and richness compared to unsalvaged-unplanted sites at Mount St. Helens, Washington. Western North American Naturalist 67: 219-231.

TURNER MG, SL COLLINS, AE LUGO, JJ MAGNUSON, TS RUPP \& FJ SWANSON (2003) Disturbance dynamics and ecological response: The contribution of long-term ecological research. Bioscience 53: 46-56.

VAN MANTGEM PJ, NL STEPHENSON, JC BYRNE, LD DANIELS, JF FRANKLIN et al. (2009) Widespread increase of tree mortality rates in the western United States. Science 323: 521-524.

WRIGHT RG (1996) Wolf and moose populations in Isle Royale National Park. In: Halvorson WL \& GE Davis (eds) Science and ecosystem management in the national parks: 74-95. The University of Arizona Press, Tucson, Arizona. 